\title{
Al literatura lésbica - Dossiê Sáfico
}

Abrimos nosso mapa de tempos e espaços. A existência lésbica, Adrienne Rich diz, se desenha no pêndulo que oscila entre desviante e o odioso. Invisível. Mas há a corrente, o continuum dessa existência persistente que, elo a elo, descortina uma nova dimensão. Nem desviante, nem odiosa: dimensão profundamente humana. Os artigos, resenha, tradução e exercício de estilo reunidos no presente número nos ajudam a cartografar esse existir. Ouviram nosso chamado e nos ajudam a recusar a extinção. E, assim, nos ajudam a respirar melhor.

Geografias lésbicas: literatura e gênero, de Natalia Borges Polesso, nos suspende do tempo histórico e nos leva para lá onde o trânsito das lésbicas e/ou mulheres queer é possivel. Artigo de asas nos pés, nos faz orbitar a Terra e nela encontrar as paisagens das letras lésbicas; e lhes dá, de presente, o mundo. Saltamos, então, do espaço sideral com vista para o globo, e Isadora Araújo Pontes nos mergulha no ponto cego. Estamos diante de Narrativas de Mulheres e da lesbiandade: discursos do 'outro lugar', onde encontramos com Violette Leduc em um tempo fora do tempo e a literatura lésbica se faz não de seu singular, mas de suas melodias plurais. E, agora, nos desintegramos para nos vermos sujeitos. Em Desfazendo o gênero: a teoria queer de Judith Butler, Eurídice Figueiredo nos coloca entre a performatividade e a performance e convida Guimarães Rosa, Amara Moira, Balzac e Marcia Tiburi a comporem nossa dimensão com suas vozes. E respiramos melhor.

Deixamos para trás as amplas paisagens e nos refazemos. Vamos nos abrigar entre (várias) quatro paredes. Encontramos, no continuum, aquela que o concebeu: O sonho de uma língua comum: a tradição segundo Adrienne Rich, de Sarah Valle Camargo, é nosso primeiro refúgio. Aqui, a existência lésbica e sua literatura se deparam com pergunta aterradora: a língua é comum para quem? e nos mostra como Rich, em sua poética, política, buscou usar a tradição para criticála. Despertamos desse mapa de nossas existências intimas e coletivas, e vamos De Marcellina à Marcela: representações em Cassandra Rios, em que Izadora Fernanda Reichert Rodrigues e Alexandra Santos Pinheiro desdomesticam o olhar comum voltado à Cassandra Rios, extrapolando a censura e os rótulos, concedendo às existências femininas um novo enredo, uma nova história. Nos vemos, logo em seguida, imersos em profundos onde há A emergência lésbica em Clarice Lispector, de Claudiana Gois dos Santos, em que conhecemos Carmem, Beatriz e sua vontade de viver dentro do espaço tempo possivel, sob um teto todo delas, um relacionamento que inove os modos de vida estabelecidos socialmente.

Chegamos, então, num sensualismo intenso onde vibram misticismos decadentes. No artigo Erotismo lésbico e experiência mística: uma leitura de Perfis decadentes, de Judith Teixeira, de Henrique Marques Samyn, desaparecem as amantes cujos gritos ainda ecoam. Aqui, a dimensão lesboerótica suspende tempo, espaço, corpo; corpo que se aniquila, justamente, para ser pleno. A poeta portuguesa será o tema também da resenha Uma Safo no modernismo português: poesia e prosa, de Judith Teixeira. Partimos rumo ao orgasmo. Contudo, La place du sadomasochisme lesbien: construction et vivabilité des plaisirs dans une nouvelle de Jane Delynn nos alerta: não se trata, simplesmente, de gozar, mas de compreender a origem do gozo e articular o gozo dissidente à normatividade comum. 
Nesse percurso, percebemos que devemos prestar atenção à língua - como o que falamos está sendo recebido? A questão evidencia também o corpo, a língua de fato, envolvida e envolvente num processo de comunicação reivindicado em sua singularidade pelo corpo dissidente. Em Falar em língua abolida: a tradução de Desglaçé, de Maria-Mercè Marçal, para o português, de Meritxell Hernando Marsal e Beatriz Regina Guimarães Barboza, vemos a poética rebelde (feminista, socialista, catalanista) da poeta catalã, que percebia uma "língua abolida" para expressar o desejo feminino - a dimensão simbólica do não-dito ou da experiência convertida em 'inefável' que resulta na invisibilidade e na mudez. Como traduzir essa língua rebelde? $\mathrm{O}$ artigo discute a percepção da poeta e ensaísta, mas nos traz também o debate sobre a tradução dessa poética para o português.

Havia uma ilha, Lesbos, e nela, nossa miragem poética, Safo. Como essa poesia grega vai ser traduzida? Em Renée Vivien, tradutora de Safo, Letticia Batista Rodrigues Leite mapeia a obra de uma das poucas tradutoras mulheres de Safo, que acentua a expressão poética lesboerótica, em escolhas ousadas que marcavam o gênero do eu-lírico - recolocando em evidência a possibilidade de expressão do homoerótica da poética grega. Podemos caminhar nessa ilha sabendo ouvir a língua de Safo.

A língua da outra. Continuemos nos domínios da tradução. Ficções lésbicas: ponto de vista e contingências, da argentina Laura Arnés, traduzida por Vitor Borysow, é a primeira parte do livro Ficções lésbicas que discute um corpus de obras que trazem aparição lésbica ou, melhor dito, das politicas de sua aparição; busca ler o momento em que a lésbica se converte em imagem ou em imaginação na literatura argentina. Esse primeiro capítulo cedido à nossa revista faz o mapeamento das dificuldades de observação do fenômeno lésbico na literatura, nos dando instrumentos em nosso percurso ao mostrar as contingências da teoria e da crítica literária lésbica como campos legítimos de reflexão acadêmica.

Embarquemos na nau Argo - a viagem aqui não tem fim, senão iniciando outros percursos. Em Notas para argonautas, Mariana Ruggieri, autora de nosso Exercício de estilo, espaço para relacionar crítica e criação literária, mostra sua leitura de The Argonauts, de Maggie Nelson (2015), mostrando como a questão queer está indissociada das questões da escrita e da necessidade de inventar e reencenar, citar e deslocar a linguagem.

Mônica Gama

Naná DeLuca

Editoras 